\title{
Blood group distribution pattern among adult who attended Federal Medical Centre, Lokoja, Kogi State, Nigeria
}

\author{
Olaniyan Olugbemi ${ }^{1}$, , Meraiyebu Ajibola ${ }^{1}$, Musa Ojone ${ }^{1}$, Dare Joseph ${ }^{2}$, Atsukwei Denen ${ }^{1}$, \\ Adelaiye Alexandra ${ }^{1}$
}

${ }^{1}$ Department of Physiology, Bingham University, Karu, Nasarawa, Nigeria

${ }^{2}$ Department of Anatomy, Bingham University, Karu, Nasarawa, Nigeria

Email address:

olugbemiolaniyan@yahoo.com(Olaniyan O.)

\section{To cite this article:}

Olaniyan Olugbemi, Meraiyebu Ajibola, Musa Ojone, Dare Joseph, Atsukwei Denen, Adelaiye Alexandra. Blood Group Distribution Pattern among Adult Who Attended Federal Medical Centre, Lokoja, Kogi State, Nigeria. American Journal of Health Research. Vol. 1, No. 3, 2013, pp. 95-98. doi: 10.11648/j.ajhr.20130103.19

\begin{abstract}
Serological markers have served as important indicators for the understanding of genetic variation between and within population, providing valuable insight into the dynamics of population structure. The present study, therefore aimed at providing the percentage frequency of the $\mathrm{ABO}$ and Rhesus distribution pattern of adults who attended the Federal Medical Centre Lokoja, Kogi State, Nigeria for record and health planning. The study was carried out on two hundred adults (77 male and 123 female). The blood samples were taken by cubital venepuncture and analysed using the agglutination method (Dacie and Lewis 2001). Among the male population; Blood group $\mathrm{O}$ was the highest with the percentage frequency of $22.5 \%$, followed by blood group A (7.5\%), B (6.5\%) and the least percentage frequency was observed in blood group $\mathrm{AB}$ with $2 \%$. Among the female population; Blood group $\mathrm{O}, \mathrm{A}, \mathrm{B} \mathrm{AB}$ had percentage frequency of $29 \%, 11.5 \%, 17.5 \%$, and $3.5 \%$ respectively. The RhD distribution also varies among male population; RhD positive $87 \%$ and $\mathrm{RhD}$ negative $13 \%$. The percentage frequency of $\mathrm{RhD}$ positive among the female population was $93.5 \%$ and that of $\mathrm{RhD}$ negative was $6.5 \%$. The total percentage of $\mathrm{RhD}$ positive was $91 \%$ and that of $\mathrm{RhD}$ negative was found to be $9 \%$. The ABO and RhD pattern in both the male and female population studied correlates with previous studies carried out in other part of Nigeria population: like Ogbomosho, Oyo State; Benin; Niger- Delta region and FCT, Abuja. Blood group $\mathrm{O}$ is the most common while Group $\mathrm{AB}$ present the least and rarity of $\mathrm{RhD}$ negative was observed in both male and female population studied.
\end{abstract}

Keywords: Blood Group, Rhesus Factor, Population, Kogi State, Nigeria

\section{Introduction}

$\mathrm{ABO}$ and Rhesus blood groups are among the most important blood groups clinically (15). Human blood groups depend on the functioning of glycosyltransferases, enzymes that catalyze the formation of glycosidic bond between monosaccharides. Specific oligosaccharide antigens attach to the proteins and lipids on the surface of erythrocytes. Those attached to proteins have a serine or threonine residue or ceramide lipid intermediate. The most basic oligosaccharide attached is called the $\mathrm{O}$ antigen (also referred to as the $\mathrm{H}$ antigen). The $\mathrm{O}$ antigen is the base oligosaccharide found in all three blood types O, A, B (18;
19). ABO blood types are inherited through genes on chromosome 9, and they do not change as a result of environmental influences during life. An individual's ABO type is determined by the inheritance of 1 of 3 alleles (A, B, or O) from each parent (6). The antigens of ABO-Rh blood group are found on the surface of red blood cell while the antibodies of ABO blood group are found in the plasma. There are two antigens and two antibodies that are mostly responsible for the $\mathrm{ABO}$ types. The specific combination of these four components determines an individual's type in most cases (6). It is a well known fact that the $\mathrm{ABO}$ blood groups are not found in equal numbers. A research carried out in Abraka campus of Delta State University discovered that amongst $\mathrm{ABO}$ system, blood 
group $\mathrm{O}$ was most common, followed by $\mathrm{A}, \mathrm{B}$ and $\mathrm{AB}$ respectively (8). Rhesus positive was more common than Rhesus negative in the rhesus system. Gender had no significant effect on both blood group systems studied. In the combined $\mathrm{ABO}$ and Rhesus blood groups, $\mathrm{O}$ positive was most common followed by A positive, B positive, AB positive, $\mathrm{O}$ negative and $\mathrm{A}$ negative respectively (13). In the study among the medical students of Madonna University Elele Nigeria, the frequency distribution of blood group $\mathrm{O}$ was the highest with percentage frequency of 15.5, 18.1 and $19.2 \%$ in Igbo, Hausa and Yoruba respectively, followed by blood group A and blood group B, and the least percentage frequency is that of blood group AB (2). Also, it has been reported in several studies that there are variation in $\mathrm{ABO}$ blood group among different ethnic groups. Many other studies have shown that blood group $\mathrm{O}$ was the most common blood group and blood group $\mathrm{AB}$ was the least common blood group in different ethnic groups (12). A study conducted at Moshood Abiola Polytechnic, Abeokuta, Nigeria among 2000 healthy students showed that $53.70 \%$ of the population have blood group $\mathrm{O}$, out of which $49.75 \%$ where $\mathrm{O}+$ and $3.95 \%$ were $\mathrm{O}$ - (9). It is well known that blood groups are associated with several diseases, like cardiovascular, obesity, osteoarthrosis, erthroblastosis in neonates and many other diseases especially, osteoporosis and suicide rate in different nations (4). Interestingly, apart from the importance of $\mathrm{ABO}$ and $\mathrm{Rh}$ blood groups in blood transfusion practice, they are useful in population genetic studies, researching population migration pattern. It is therefore, imperative to have information on the distribution of these blood groups in any population group that comprise different ethnic groups. This study therefore was aimed at having information on the distribution of $\mathrm{ABO}$ and $\mathrm{Rh}$ blood group among adult who attended Federal Medical Centre, Lokoja, Kogi State, Nigeria.

\section{Materials and Methods}

\subsection{Sample Collection and Experimental Procedure}

A total of 200 adults (77 male and 123 female) were randomly selected among adult who attended Federal Medical Centre, Lokoja, Kogi State, Nigeria. Blood samples were collected by venepuncture and analysed using the agglutination method. The blood was transferred into prepared ethylenediamine tetracetic acid (EDTA) anticoagulant bottle.

\subsection{ABO and Rh Blood Group Tests}

The ABO and Rhesus blood grouping were done using the tile method. A drop of blood from each subject was placed on a clean white tile in three places. A drop of each of the antisera, anti A, and anti B and anti D was added and mixed with each blood sample with the aid of glass rods. Blood was mixed thoroughly with the antisera and rocked gently for $60 \mathrm{sec}$ to observe agglutination. In case of doubt, the test was examined under a microscope and the results were confirmed by reverse grouping using known group A and $B$ red cells (5). Data on the frequency of $\mathrm{ABO}$ and $\mathrm{Rh}$ blood groups were reported in simple percentages.

\section{Statistical Analysis}

All data were analysed using the Statistical Package for Social Science (SPSS Inc., Chicago, IL) software package 13. The distribution of different blood groups was compared between males and females using independent " $\mathrm{t}$ " test. In addition, the association of the different blood groups within the tribes and the distribution of blood groups obtained in the present study were determined using the one-way analysis of variance (ANOVA) with Duncan's Post-hoc analysis. P - value of $\leq 0.05$ was considered to be statistically significant.

\section{Result}

Table I. ABO Blood Group frequency Distribution among Male and Female Adults Who Attended Federal Medical Centre Lokoja, Kogi State, Nigeria. $(n=200)$.

\begin{tabular}{cccccc}
\hline Sex & A & B & AB & O & TOTAL \\
\hline \multirow{2}{*}{ Male } & 15 & 13 & $4(2 \%)$ & 45 & 77 \\
& $(7.5 \%)$ & $(6.5 \%)$ & & $(22.5 \%)$ & \\
Female & 23 & 35 & 7 & 58 & 123 \\
& $(11.5 \%)$ & $(17.5 \%)$ & $(3.5 \%)$ & $(29 \%)$ & \\
Total & 38 & 48 & 11 & 103 & 200 \\
& $(19 \%)$ & $(24 \%)$ & $(5.5 \%)$ & $(51.5 \%)$ & \\
\hline
\end{tabular}

There is no significant relationship between male and female students in their blood group.

The results showed that there are no significant differences $(\mathrm{P}>0.05)$ in the frequency of blood group distribution among the male and female Adults Who Attended Federal Medical Centre Lokoja, Kogi State, Nigeria. Blood group A, B, AB, O had 38 (19\%), 48 (24\%), $11(5.5 \%)$, and $103(51.5 \%)$ respectively. The result is similar to the result obtained by (3) among 7653 individuals in Ogbomosho, Oyo state in Nigeria where blood group A, B, AB, O had $22.9 \%, 21.3 \%, 5.9 \%$ and $50 \%$ respectively. Also in Benin, Niger-Delta region of Nigeria blood group distribution among 160,431 individuals showed phenotypes $\mathrm{A}, \mathrm{B}, \mathrm{AB}, \mathrm{O}$ as $23.7 \%$, $20.1 \%, 2.97 \%$ and $53.2 \%$ respectively (7). And also in FCT, Abuja blood group distribution among 305 indigenes showed blood group A to be $21.6 \%$, B $26.2 \%$, AB $4.9 \%$ and $\mathrm{O} 47.2 \%$ (14).

Out of the two hundred (200) individuals used for this study, 77 were males and 123 were females as seen in table III below. Rh-positive were $182(91 \%)$ and Rh-negative were $18(9 \%)$. 
Table II. ABO - RH Blood Group Distribution Among Adults Who Attended Federal Medical Centre Lokoja, Kogi State, Nigeria $(n=200)$.

\begin{tabular}{ccc}
\hline ABO Blood & RhD & RhD \\
\hline Group & Positive & Negative \\
\hline A & $33(18.13 \%)$ & $5(27.78 \%)$ \\
B & $46(25.27 \%)$ & $2(11.11 \%)$ \\
AB & $9(4.95 \%)$ & $2(11.11 \%)$ \\
O & $94(51.65 \%)$ & $9(50 \%)$ \\
Total & $\mathbf{1 8 2 ( 1 0 0 \% )}$ & $\mathbf{1 8 ( 1 0 0 \% )}$ \\
\hline
\end{tabular}

There is no significant difference between Rhesus positive and Rhesus negative students.

Table III. Rh Blood Group Distribution Among Male And Female Adults Who Attended Federal Medical Centre Lokoja, Kogi State, Nigeria $(n=$ 200).

\begin{tabular}{cccc}
\hline Sex & Rh D Positive & Rh D Negative & Total \\
\hline Male & $67(87 \%)$ & $10(13 \%)$ & $77(100 \%)$ \\
Female & $115(93.5 \%)$ & $8(6.5 \%)$ & $123(100 \%)$ \\
Total & $182(91 \%)$ & $18(9 \%)$ & $200(100 \%)$ \\
\hline
\end{tabular}

\section{Discussion}

From this study, the distribution of blood group $\mathrm{O}$ was the highest with percentage frequency of $51.5 \%$, followed by blood group B and A with percentage frequency of 24 and $19 \%$ respectively and the least percentage frequency is that of blood group $\mathrm{AB}$ which is $5.5 \%$ as observed in the previous studies $(3 ; 7 ; 14)$. Normally, the distribution of ABO blood group varies from one population to another $(12 ; 10 ; 8)$. In many other studies, blood group $\mathrm{O}$ has been found to be the most common blood group $(12 ; 14)$. In Lagos, Nigeria, blood group $\mathrm{O}$ is $55.3 \%$, blood group A, $25.3 \%$, blood group B, $16.7 \%$ and blood group AB, $2.7 \%$ (1). Thus, the segregation of the genes responsible for the ABO blood groups has always taken a particular pattern for its distribution. In this study, it can be seen that blood group $\mathrm{AB}$ has the least percentage; which is most of the time very rare and also the case in other previous studies. Rhesus D distribution also varies within any group of human population. In this study, it was observed that blood group $\mathrm{O} \mathrm{Rh} \mathrm{D}$ positive is the highest with a percentage frequency of $51.7 \%$, which is followed by group $\mathrm{B} \mathrm{Rh} \mathrm{D}$ positive with the percentage frequency of $25.3 \%$, blood groups A $\mathrm{Rh} \mathrm{D}$ positive is $18.1 \%$ and $\mathrm{AB} \mathrm{Rh} \mathrm{D}$ positive $5.0 \% \mathrm{Rh}$ factor positive is more in the female population $(93.5 \%)$ than the male population while $\mathrm{Rh}$ factor negative is found more in the male population $(13 \%)$ than in the female population. This study showed a total percentage of Rh D positive distribution of $91 \%$ and $\mathrm{Rh} D$ negative distribution to be $9 \%$. Similar pattern of distribution is also observed in other studies which showed rarity of $\mathrm{Rh}$ negative (14). This study further confirmed that Rh positive has the highest percentage frequency while $\mathrm{Rh}$ negative has the lowest percentage frequency as observed in previous studies among different ethnic groups $(12 ; 8)$. In addition,
Worlledge et al. (16) reported the incidence of rhesus negativity in Nigeria, which was found to be between 1.69 and $5.5 \%(17)$. Their finding confirmed the trend of the relatively low incidence of rhesus negativity in the country and even in the African population. However, over the years, the $\mathrm{Rh}$ blood group system has been distributed among many populations to keep the frequency of $\mathrm{Rh}$ negative very low. This similar pattern of distribution is also observed in this study and other studies.

\section{Conclusion}

Knowledge of the distribution of $\mathrm{ABO}$ and $\mathrm{Rh}$ blood groups among any population is useful in health care planning and appropriate allocation of resources, while counselling targeted at appropriate persons ensures the general well being of the individuals or people.

\section{References}

[1] Adeyemo OA, and Soboyejo OB, (2006). Frequency distribution of $\mathrm{ABO}, \mathrm{RH}$ blood groups and blood genotypes among the cell biology and genetics students of University of Lagos, Nigeria African Journal of Biotechnology Vol. 5 (22), pp. 20622065 ,

[2] Akinjide M. A, Bamidele O, Amosu M.A and Ugwa U. G, (2011). Distribution of $\mathrm{ABO}$ and $\mathrm{Rh}$ Blood Groups among Major Ethnic Groups of Medical Students of Madonna University Teaching Hospital, Elele, Nigeria. Asian Journal of Medical Sciences 3 (3): 106-109.

[3] Bakare, A.A., Azeez M.A. and Agbolade, J.O. (2006). Gene frequencies of $\mathrm{ABO}$ and rhesus blood groups and haemoglobin variants in Ogbomoso, South-West Nigeria. Afr. J. Biotechnol., 5(3): 224-229.

[4] Chihara, Y., Sugano, K., Kobayashi, A., Kanai, Y., Yamamoto, H., Nakazono, M., Fujimotom., H., Kakizoe, T., Fujimoto, K., Hirohashi, S. and Hirao, Y. (2005). Loss of blood group A antigen expression in bladder cancer caused by allelic loss and/or methylation of the ABO gene. Lab Invest. 9:158-167.

[5] Dacie, J.V. and S.M. Lewis, 2001. Practical Haematology. In Lewis, S.M., B.J. Bain, I. Bates, (Eds.), 9th Edn., Churchill Livingstone, Harcourt Publishers Limited, London, pp: 444-451.

[6] Dennis, Y.M., N.M. Hylem, C. Fidler, I.L. Sargent and M.F. Murphy et al., 1998. Prenatal diagnosis of fetal RhD status by molecular analysis of maternal plasma. New Engl. J. Med., 337: 1734-1738. PMID: 9845707

[7] Enosolease ME and Bazuaye GN (2008): Distribution of $\mathrm{ABO}$ and Rh-D blood groups in Benin area of the Niger Delta: Implication for Regional Blood Transfusion. Science; 2 (1): 3-5.

[8] Falusi, A G Ademowo, O G Latunji, C A Okeke, A C Olatunji, P O Onyekwere, T O Jimmy, E O Raji, Y Hedo, C C Otukonyong, E E and Itata, E O (2000). Distribution of $\mathrm{ABO}$ and $\mathrm{RH}$ genes in Nigeria African journal of medicine and medical sciences; 29 (1): 23-6. 
[9] Idowu O, and Sade S, (2008). ABO and Rhesus ' $\mathrm{D}$ ' blood type distribution in students admitted into Moshood Abiola Polytechnic, Abeokuta, Nigeria in 2006. African Journal of Biotechnology Vol. 7 (11), pp. 1641-1643.

[10] Kulkarni AG, Peter B, Ibazebo R, Dash B, and Fleming AF, (1985). The ABO and Rhesus groups in the north of Nigeria. $79(1): 83-8$.

[11] Lester, D. (2005). Predicting suicide in nations. Suicide Res. 9: $219-23$

[12] Nwauche, C.A. and O.A. Ejele, (2004). ABO and Rhesus antigens in a cosmopolitan Nigeria population. Niger J. Med., 13 (3): 263-266.

[13] Odokuma EI, Okolo AC, and Aloamaka PC, (2007). Abstract; Distribution of $\mathrm{ABO}$ and rhesus blood groups in Abraka, Delta State, Nigeria. 22 (1-2): 89-91.

[14] Olaniyan OT, Meraiyebu AB, Rasong H, Dare BJ, Shafe MO and Adelaiye AB (2013): Blood Group and Rhesus Factor Pattern among indigenes of FCT, Abuja, Nigeria. Journal of Community Medicine and Health Education 3: 208
[15] Seeley RR, Stephens TD, and Tate P, (1998). Anatomy and Physiology. $4^{\text {th }}$ edition. The McGraw Hill Companies, Inc. USA p. 1098

[16] Worlledge, S. Ogiemudia, S.E. Thomas, C.O. Ikoku B.N and Luzzutto, L. (1974). Blood group antigens and antibodies in Nigeria. Ann. Trop. Med. Parasitol., 68: 249-264.

[17] Worlledge, S. Mourant, A.E., Kopec A.C. and Domaniewskasobczak, K. (1966). The Distribution of the Human Blood Groups and Other Polymorphsisms. Oxford University Press, London, pp: 117-122.

[18] Nelson M, Ashenden M, Langshaw M et al (2002) Detection of homologous blood transfusion by flow cytometry: a deterrent against blood doping. Haematologica 87:881-882.

[19] Nelson M, Popp H, Sharpe K et al (2003). Proof of homologous blood transfusion through quantification of blood group antigens. Haematologica 88: 1284-1295 